(7)

\title{
Challenges for Federalism in Pakistan, Post Musharraf Era
}

\author{
${ }^{a}$ Ghulam Ali, ${ }^{\text {b }}$ Razia Musarrat \\ ${ }^{a}$ PhD Scholar, Department of Political Science, The Islamia University of Bahawalpur, Pakistan \\ Email: g.ali666 @yahoo.com \\ ${ }^{\mathrm{b}}$ Professor, Department of Political science, The Islamia University of Bahawalpur, Pakistan \\ Email: drrazia_mussarat@yahoo.com
}

\begin{tabular}{|c|c|}
\hline ARTICLE DETAILS & \multirow{10}{*}{$\begin{array}{l}\text { ABSTRACT } \\
\text { Federalism is a form of government that solves the challenges of } \\
\text { diversity of a state. Many ethnic groups resides in Pakistan .Baluchistan } \\
\text { is the biggest province having smallest number of population of the state } \\
\text {,Punjab the dominant province in terms of population and size has } \\
\text { further divisions on linguistic and territorial grounds. Small provinces } \\
\text { always raised their voices against the unjust sharing of resources, } \\
\text { administrative posts and political positions. The study reveals that } \\
\text { mostly resources and political and administrative positions are shared } \\
\text { by the two dominant provinces, Punjab and Sindh and other federating } \\
\text { units and regions are usually deprived from these prestigious positions } \\
\text { that is causing unrest in those regions which is very harmful for the } \\
\text { integration of the state. Post Musharraf era in Pakistan is witnessing a } \\
\text { continuity of democratic regimes in the state and democratic } \\
\text { government of Yousaf Raza Gailani shared maximum powers to the } \\
\text { provinces in the form of } 18 \text { th Amendment but still state of Pakistan has } \\
\text { to do a lot more for solving the issues of the provinces. }\end{array}$} \\
\hline History: & \\
\hline Accepted 12 March 2020 & \\
\hline Available Online 31 March 2020 & \\
\hline & \\
\hline & \\
\hline Challenges. Units & \\
\hline JEL Classification: & \\
\hline H77, H7O, H79 & \\
\hline DOI: $10.47067 /$ reads.v6i1.184 & \\
\hline
\end{tabular}

(C) 2020 The authors. Published by SPCRD Global Publishing. This is an open access article under the Creative Commons Attribution-

NonCommercial 4.0

Corresponding author's email address: g.ali666 @yahoo.com

\section{Introduction}

So far, Pakistan has lagging far behind from becoming a true and participatory federalism. Image of masses about Pakistan as a federal state is totally different from that of bureaucrats, elites and politicians. Post Musharraf era has experienced elections for three times in 2008, 2013 and 2018 and democratic governments restructured the political system of Pakistan by amending the constitution but federalism in Pakistan is still facing many challenges that are deteriorating the integration of the state. In this article these challenges are discussed so that a viable solution could be presented.

\section{Literature Review}

Rehana saeed Hashmi says that besides the constitutional arrangements only federalism can diffuse the ethnic tensions. The focus of article "Ethnic Politics: An issue to national integration (The Case Study of Pakistan)" is on the diversity and national integration and representation .But the work 
does not disclose how these ethnic tension can be removed (Hashmi, 2015). Asma Faiz (2015) presents his ideas about federalism and also explains why federalism requires re-examining to meet the present era challenges. The book is a collection of articles that deals with all dimensions of federalism. It begins with the political and constitutional origin of Pakistani federalism then an article by Muhammad Waseem explains that Pakistan is a majoritarian federalist state. Arshad Javaid Burki in his two articles took a view of 18th Amendment and termed it as restructuring and redesigning of the constitution of Pakistan. Besides all this the work fails to point out existing challenge of FATA, situation of federation after 18th amendment and challenges posed by 18thamendment for federal system of Pakistan. Nasreen Akhtar describes that there are two main reasons of ethnic tension in a state, identity crises and fragile economic conditions. According to her it was the ethnicity that destroyed the interprovincial harmony that caused dismemberment of Pakistan (Akhtar, 2015)

Asim describes that federalism in Pakistan is in fragile condition this is due to the broken history of democracy in Pakistan. Politicians never tried to strengthen democracy and the generals have to take the charge of the federalism in Pakistan. Federalism is suffering in Pakistan due to Punjabi dominance .A move for shrike province is started in the Southern Punjab, if this is succeeded, that will end the dominance of Punjab in Pakistan .He does not taken into account the challenges in the creation of new provinces in Pakistan (Sajjad, 2015).

Amir Hanif and Shehbaz Hussain describe about the threats and challenges that the federation of Pakistan is facing in the form of corruption, religious millitancy, etnicity, social and political exclusion. Their point of view is that although 18th Amendment has reshaped the federalism in Pakistan, linguistic ethnicity is deteriorating the federal basis of the state (Shehbaz, 2015). Muhammad Iqbal Chawla and Anjum Zia (2018) have taken a view of the 18th amendment, especially the relations of Punjab and central government during the years from 2008 to 2013 in their article Re-contextualizing the 18th Amendment: Working of Federalism in Pakistan. According to the writers the 18th amendment has strengthened the federalism in Pakistan by transferring the concurrent list to the province.

\section{Research Methodology}

The article is based on descriptive and analytical methodology. The data for this article is collected through secondary sources and for this purpose article published in various journals and books on the topics of federalism and power sharing are consulted. Some statistical data is also collected through different websites of government of Pakistan.

\section{Money Laundering and Corruption}

A big challenge that the federalism of Pakistan is facing currently is the corruption and its acceptance at social level. Corruption is a big hurdle in the economic development of the state and Pakistan is constantly borrowing from the international donors' agencies and its friendly states. The situation is so worst that the federation of Pakistan has to borrow loans for returning the installments of the old loans. It is only because of the corruption. Many peoples working in every administrative, political or social department are indulged in corrupt practices. But the issue is not only the corruption rather its acceptance as a social evil and taking it lightly by the society and the political system is the real problem. Bureaucrats, businessmen and politicians all have accepted it as a social norm and granted it legitimacy (Ahmad, 2010).Many religious minded and fair persons have raised their voices against this social evil but so far proved useless. PTI chairman Imran Khan started a compaign against the corruption and money laundering in the state and his sit in Islamabad was against the corruption of politicians that helped to some extent for producing awareness in the society. After coming into power in 2018 his government took radical steps for eradicating corruption and money laundering from the 
state. Both the evils are destroying the spirit of federalism from the political system of Pakistan.

\section{Linguistic Crises and Challenges}

Lingual diversity is the key feature of the Pakistani federalism. More than six main and near about fifty nine minor languages are being spoken in the state. This is at one side is the cultural strength of the federation but at the other side is the matter of concern for Pakistan. Pakistan's policy makers always remained unaware from the power of this diversity and no effort is made to use this diversity for producing social capital or for uniting the federation of Pakistan. Lingual conflict has broken the federation of Pakistan in past when founding fathers announced and rulers of West Pakistan tried to enforce Urdu as the national language. In reaction political leadership of East Pakistan tried to make Bengali as the main language of the state. Although the conflict was solved in the constitution of 1956 and again in the constitution of 1962 by declaring Urdu and Bengali both as the national languages of the state but the grievances started in the beginning of the federalism in Pakistan were never minimized. It resulted into the dismemberment of Pakistan. State policies are favoring English and Urdu and the regional languages have never gain importance in Pakistan. Even Urdu has not made yet the official language of the State that is the reason of failure of many students in different level exams. Presently many languages are in danger of elimination from this part of the world and their speakers are raising their voices for the survival of their mother tongues. Saraiki and Hazarvi speaking people are demanding their separate provinces to keep their identity intact. Mohajirs of Sindh are wishing their separate province to save their cultural symbol Urdu. But the question is that whether the state is ready to face this situation by making new provinces or this issue will remain unresolved for the creation of hurdles for a well balanced, united and peaceful federation of Pakistan.

\section{Challenge of Diversity}

Every federal state has to face diversity and infarct federalism is adopted only to manage the diversity of the state. Ethnicity in Pakistan started on racial grounds in Balochistan in 1948 that converted into a conflict which is still a danger for the unity of the state. Instead of dissolving the ethnic tensions ,the policies of ruling class is increasing grievances of the masses(Majeed, 2014).Many small ethnic groups residing in different provinces are demanding their identity in the form of their own province but constitutional ,economic and administrative problems are big hindrance in the way of becoming Pakistan a collaborative federalism. Un balanced economic growth of different regions, military dictatorships and lack of rule of law are major issues that are creating ethnic tensions in the state.

In Pakistan mainly ethnic tensions are created on the bases of sect, language and provincialism. Pakistan faced Shia Sunni conflict that was based on the sectarian grounds. The intensity of this conflict was seen from Zia ul Haq rule to till the era of Pervaiz Musharraf. In this conflict the Mosques and religious educational institutes (Madrassas) of the opposite sect were attacked and hundreds of the people were killed. Musharraf put ban on sectarian organizations to stop this ethnicity. Sindhi Mohajir and then Pashtun Mohajir conflict on the linguistic grounds ruined the peace of Karachi (Majeed, 2014).This linguistic ethnicity was crushed in army actions during Nawaz Sharief Era. Decision makers of the state try to make policies for controlling the ethnic tensions but still effective measures needed to be taken by the authorities.

\section{Issue of Sharing the Resources}

Smaller federating units have many complaints about the distribution of finances, water, gas, electricity and of the developmental projects of the federal governments. According to them as the Punjab has the major share in federal bureaucracy and in political positions they always try to give major share to Punjab. Sindh is demanding more share of natural gas .From 2008 to 2018 Pakistan is 
facing energy crises that are proving negative in industrial and social development of the provinces. Chief Minister of Sind Sayed Murad Ali Shah has stated again that Sindh is the main producer of Natural gas and the people of Sindh are facing the most shortage of gas. They must provide their share according to their needs. The other issue of the small provinces and the remote areas of Punjab is the low share in the CPEC projects. They have always been complaining about their low representation in political positions. Here these reservations have been discussed in detail.

\section{Allocation of Funds: NFC Award}

In Pakistan, the smaller units have been arguing that the formula of N FC Award benefits the Punjab. NFC Award has remained a bone of contention among provinces and it was only three times since 1973 that National Finance Commission announced its recommendations. Fiscal sharing's from the centre to the provinces are necessary for development of the federating units. According to the 18th Amendment, once the share from NFC award allotted to any province was never be reduced. This provision has halted the complete mergence of FATA to KPK.According to the recommendations of FATA reforms committee, 3 percent share from the NFC award should be given to FATA but no province is ready to reduce its share .According to the NFC Award of 1997 population based formula for sharing of finances was adopted .Balochistan received 5.3 percent KPK, 13.54, Sindh 23.28 and Punjab 57.88 percent. At that time nothing was allotted for FATA and now this is the major hurdle for integration of FATA to KPK.

\section{Under-Representation in Political Offices; a Political Challenge}

Federalism is the method of economic and social up gradation of small ethnic groups. Representation of these groups in key political positions is a source of uplift for them. In a federation like Pakistan where one ethnic group or province dominates the federalism due to its numerical majority, special arrangements for the equal representation of small ethnic groups should be adopted otherwise these groups feel themselves oppressive that give birth to a conflict with in federation. Under representation of small constituent units in the political offices is a big challenge for federalism in Pakistan that is creating a sense of deprivation in the people of Balochistan, Fata and KPK. The main issue of the small provinces particularly of KPK and especially of Balochistan is lack of power sharing and under representation in political offices. Their basic grievance is that they are not getting their due share in political positions and are being excluded from the power structure of Pakistan The ethnolinguistic groups residing in small provinces in Pakistan have concerns that their representation in National and provincial legislatures is very low that is why they are being deprived from the esteemed political offices like Prime Minister, President, Chairman Senate and Speaker of National Assembly. They believe that larger share of political positions is beneficial for them. The evidence also shows that the concerns of the small province like KPK and Balochistan are true because the post dismemberment history of Pakistan reveals that Zafrullah Khan Jmali of Balochistan is the only person who became Prime Minister of Pakistan but no one from KPK.As for office of President is concerned only one person is elected as president of Pakistan i.e. Ghulam Ishaq Khan from KPK but not a single person from Balochistan, FATA and Gilgit Baltastan. The representation of small ethnic groups must be increased for the solidarity of the federation of Pakistan.

Table 1 Under representation of KPK and Balochistan in Political Positions (Provincial Origins of Prime Ministers of Post-1971 Pakistan)

\begin{tabular}{|l|l|l|l|l|l|}
\hline S\# & Name & Duration & $\begin{array}{l}\text { Period } \\
\text { Y- M- D }\end{array}$ & Province & $\begin{array}{l}\text { Elected or } \\
\text { Caretaker }\end{array}$ \\
\hline 1 & Zulfiqar Ali Bhutto & August 14, 1973 to July 5, 1977 & O3-10-22 & Sindh & Elected \\
\hline $\mathbf{2}$ & Muhammad Khan & M arch 24, 1985 to May 29, & 03-02-05 & Sindh & Elected \\
\hline
\end{tabular}


Review of Economics and Development Studies, Vol. 6 (1) 2020,

\begin{tabular}{|c|c|c|c|c|c|}
\hline & Junejo & 1988 & & & \\
\hline 3 & Benazir Bhutto & $\begin{array}{l}\text { December 2,1988 to August 6, } \\
1990\end{array}$ & $01-08-04$ & Sindh & Elected \\
\hline 4 & $\begin{array}{l}\text { Ghulam Mustafa } \\
\text { Jatoi }\end{array}$ & $\begin{array}{l}\text { August } 6,1990 \text { to November } 6 \text {, } \\
1990\end{array}$ & OO-O3-00 & Sindh & Caretaker \\
\hline 5 & Nawaz Sharif & $\begin{array}{l}\text { November 6, } 1990 \text { to April 18, } \\
1993\end{array}$ & $02-05-12$ & Punjab & Elected \\
\hline 6 & Balakh Sher Mazari & April 18, 1993 to May 26, 1993 & $00-01-22$ & punjab & Caretaker \\
\hline 7 & Nawaz Sharif & May 26,1993 to July 18,1993 & 00-01-08 & Punjab & Elected \\
\hline 8 & $\begin{array}{l}\text { Moeenuddin } \\
\text { Ahmad }\end{array}$ & July 18,1993 to October 19,1993 & 00-03-01 & Punjab & Caretaker \\
\hline 9 & Benazir Bhutto & $\begin{array}{l}\text { October19, } 1993 \text { to November } 5 \text {, } \\
1996\end{array}$ & $03-00-16$ & Sidh & Elected \\
\hline 10 & Miraj Khalid & $\begin{array}{l}\text { November 5, } 1996 \text { to February 17, } \\
1997\end{array}$ & $00-03-12$ & Punjab & Caretaker \\
\hline 11 & Nawaz Sharif & $\begin{array}{l}\text { February } 17,1997 \text { to October } 12, \\
1999\end{array}$ & $02-07-25$ & Punjab & Elected \\
\hline 12 & $\begin{array}{l}\text { Zafarullah Khan } \\
\text { Jamali }\end{array}$ & $\begin{array}{l}\text { November 21, } 2002 \text { to June } 26 \text {, } \\
2004\end{array}$ & 01-07-05 & Baloch & Elected \\
\hline 13 & Shujaat Hussain & June 30,2004 to August 28, 2004 & $00-01-28$ & Punjab & Elected \\
\hline 14 & Shaukat Aziz & $\begin{array}{l}\text { August } 28,2004 \text { to November } 15 \text {, } \\
2007\end{array}$ & $03-02-17$ & Punjab & Elected \\
\hline 15 & M. MianSomoro & $\begin{array}{l}\text { November } 15,2007 \text { to march } 25, \\
2008\end{array}$ & $00-04-10$ & Sindh & Caretaker \\
\hline 16 & Yousaf Raza Gillani & March 25, 2008 to June 19,2012 & $04-02-25$ & Punjab & Elected \\
\hline 17 & Raja Pervaiz Ashraf & 22 June 2012 to 24 March 2013 & $0-09-12$ & Punjab & Elected \\
\hline 18 & $\begin{array}{l}\text { Mir Hazar Khan } \\
\text { Bajrani }\end{array}$ & 25 March 2013 to 5 June 2013 & $0-02-11$ & Sindh & Caretaker \\
\hline 19 & Nawaz Sharif & 5 June 2013 to 28 July 2017 & $04-01-23$ & Punjab & Elected \\
\hline 20 & $\begin{array}{l}\text { Shahid Khaqan } \\
\text { Abbasi }\end{array}$ & O1 August 2017 to 31 May 2018 & $00-01-20$ & Punjab & Elected \\
\hline 21 & Nasir ul Mulk & o1 June 2018 to 18 August 2018 & $00-02-18$ & KPK & Caretaker \\
\hline 22 & Imran Khan & 18 August 2018 to date & & Punjab & Elected \\
\hline
\end{tabular}

Source: compiled by the researcher

In the above table, it is clear that prestigious position of Prime Minister was never enjoyed by any person from FATA besides being the territory of Pakistan. This position went to Balochistan only for one tme for the period of about one and half year when Zafrullah Khan Jamali was elected as Prime Minister of Pakistan on November 21,2002.The situation of KPK is much worst than Balochistan. So far only one caretaker prime minister is appointed from that province. This situation is very negative for the harmony of the federalism in Pakistan.

Table 2 Under representation of KPK and Balochistan in Political Positions (Presidents of Pakistan Post-1971 Era)

\begin{tabular}{|l|l|l|l|l|l|}
\hline S\# & Name & Duration & $\begin{array}{l}\text { Period } \\
\text { Y- M- D }\end{array}$ & Province & $\begin{array}{l}\text { Elected or } \\
\text { Non Elected }\end{array}$ \\
\hline
\end{tabular}


Review of Economics and Development Studies, Vol. 6 (1) 2020,

$57-65$

\begin{tabular}{|c|c|c|c|c|c|}
\hline 1 & Zulfiqar Ali Bhutto & $\begin{array}{l}\text { December 20,1971-- August 13, } \\
1973\end{array}$ & $01-08-23$ & Sindh & Non- elected \\
\hline 2 & $\begin{array}{l}\text { Fazal Ilahi } \\
\text { Chaudhry }\end{array}$ & $\begin{array}{l}\text { August } 13,1973 \text { - September } 16 \text {, } \\
1978\end{array}$ & $05-01-03$ & Punjab & Elected \\
\hline 3 & Zia-ul-Haq & $\begin{array}{l}\text { September 16, } 1978 \text { - August 17, } \\
1988\end{array}$ & $09-11-01$ & Punjab & Non- elected \\
\hline 4 & $\begin{array}{l}\text { Ghulam Ishaq } \\
\text { Khan }\end{array}$ & August 17,1988 - July 18, 1993 & $04-11-01$ & KPK & Elected \\
\hline 5 & $\begin{array}{l}\text { Farooq Ahmad } \\
\text { Khan }\end{array}$ & $\begin{array}{l}\text { November 14, } 1993 \text { - December } \\
2,1997\end{array}$ & $04-00-18$ & Punjab & Elected \\
\hline 6 & Muhammad Rafiq & o1January, 1998 to June 20, 2001 & $03-05-19$ & Punjab & Elected \\
\hline 7 & Pervez Musharraf & $\begin{array}{l}\text { June } 20,2001 \text { to August 18, } \\
2008\end{array}$ & $07-01-28$ & Mohajir & Non- elected \\
\hline 8 & Asif Ali Zardari & $\begin{array}{lcccc}\text { September } 9, & 2008 & \text { to } & 9 \\
\text { September } 2013 & & & \\
\end{array}$ & $05-0-0$ & Sindh & Elected \\
\hline 9 & Mamnoon Hussain & $\begin{array}{l}9 \text { September } 2013 \text { to } 9 \text { stember } \\
2018\end{array}$ & $05-0-0$ & Sindh & Elected \\
\hline 10 & Arif Alvi & 9september 2018 to date & $01-03-21$ & Mohajir & Elected \\
\hline
\end{tabular}

Source: Compiled by the Researcher. Period has been calculated up to December, 31, 2019.

\section{Under Representation in Bureaucracy}

Political system of Pakistan is deeply influenced by the civil bureaucracy throughout the political history of the state. Weak political institutions, fractions among the politicians, and power game of political leadership have given bureaucracy an opportunity to take part in state building and nation building process to a greater extent.

Before the failure of the federation on December 16, 1971 besides the presence of ethnic cleavages in west Part of the federation, the focus was made on East-West representation of bureaucracy in the country. Although Bengalis had more population than the rest of Pakistan but their representation in the bureaucracy was not according to their strength. Situation in 1956 was that out of 741 top policy making posts in civil secretariat only 51were Bengalis. As for military bureaucracy is concerned officers in navy, air force and army mostly belonged to the West Pakistan and their strength was near about 98 percent and the remaining 2 percent were Bengalis (Islam, 1981). According to Samad the main cause for under representation of Bengalis in bureaucracy in early years were the British recruitment policies. They did not provided opportunities to different regions of British India for equal representation in bureaucracy. That is the reason that out of " 133 Muslims from the top layer of the bureaucracy who opted for Pakistan, only one was Bengali and the rest were mainly the Mohajirs and the Punjabis" (Samad, 1995, p.128).

The early years of Pakistan are marked with the Punjabi; Mohajir domination in bureaucrats and after the dismemberment of federalism in 1971, in Pakistan Punjabis emerged as the dominant ethnic group with their dominance in bureaucracy. The Mohajirs also got their share in top bureaucracy more than their numerical strength in the early decades but since 1980s they have lost their over representation in top bureaucrats posts (Raman, 1995). Later on the quota system adopted by the central government for the appointment of top bureaucrats slightly increased the representation of small ethnic groups but still Punjab and urban Sindh is enjoying the over representation in top federal services. 
During general Zia's regime (1977-88) Punjabi dominance not only further increased but it gave way to the Pashtuns to rise as the junior partners of Punjabis in all type of bureaucracy (Ahmed, 1988).But on the other hand Sindhis and Baloches remained underrepresented in civil and military bureaucracy. In 1972, the representation of Baloch peoples was only 5 per cent and they were mostly on low ranked jobs in the civil services (Ali, 1983, p. 117).The situation in 2018 is still alarming in the representation process. The following table shows that on grade 22 from the actual filled posts 65 top bureaucrats belonged to Punjab while only six from Balochistan Sindh in total 11, KPK 15 while FATA, Gilgit Baltistan, and Azaad Jammo o Kashmir has not a single person's representation at this grade. In Scale 21 from Punjab 242, Sindh 67 in total, Kpk 71, Balochistan 8 AJK 4, G.B 2 and from FATA only 8 persons are representing their respective areas. The representation in civil services from scale 22 to 17 discloses that out of 221556 total actual filled posts federal capital shares 249, Sindh Rural 1671, Sindh Urban 1567, KPK 2993, Balochistan 871, AJK 315, G.B 1728, FATA 380 while only from Punjab 12832 civil bureaucrats are holding key positions in bureaucracy. The continuing underrepresentation of different areas of federation is causing resentments in the people of the small units that are a serious threat for the federation of Pakistan. Jobs in civil services of Pakistan not only provide mean of living to the masses but it also is the symbol of honor for the people. Small ethnic groups generally are less educated or uneducated. After the 18th Amendment education is the basic right of the people and this is now the responsibility of provincial governments to increase the educational standard in their respective provinces.

Table 3 Representation of Provinces in Civil Services in 2018

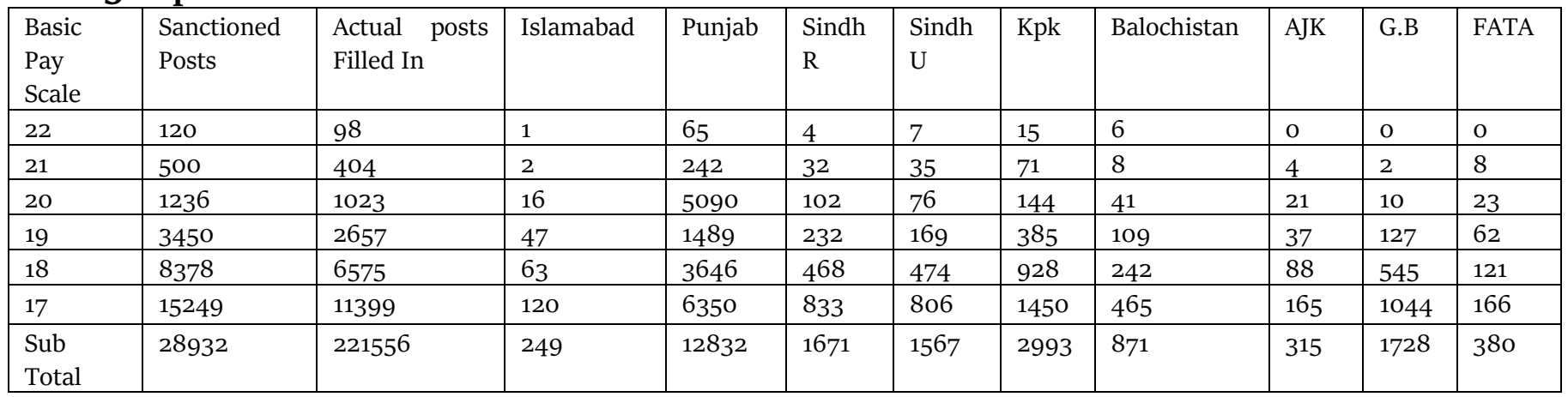

Source: Federal Bureau of Statistics Pakistan

\section{Challenge of Water Conflict for the Federalism in Pakistan}

Natural resources like water, crude oil, natural gas, coal and gold have remained a major cause of conflict among nations, nationalities, communities and societies because of their economic importance. In the modern era with the adaptation of resource-fed method of development these resources has also got political values in federalist states. Among these natural resources, water has its special importance for agri based federal countries. In the Past water had been a major cause of war that was fought before 4500 year ago between the city states of Lagash and Umma in the region of Tigris-Euphrates. Nature has provided water to his creatures in abundance but the problem according to Amit Ranjan is "but 97.5 percent of the world's water is too salty for human consumption and crop production. Even the rest of the fresh water, an estimated 35 million cubic kilometers (million cu $\mathrm{km}$ )/year, cannot be fully accessed; most of it is locked either in the ice cover of Arctic and Antarctic regions or in deep underground aquifers" (Ranjan, 2012).

Approximately two-thirds of water that is accessible and known as green water goes to the environment due to the evaporation process and cause rains and snow falls and thus creates an ecological balance. Remaining water that is recognized as blue water, and is useable but its utilization is 
difficult because of technological, environmental and economic, limitations. This is the reason of scarcity of water in the world and different states have less water resources in compliance with their needs. But availability of water is different for different states, Brazil that is less populated country in the world has one-fifth of world's water reservoir son the other hand China and India besides having one-third of world's population controls just one-tenth of global fresh water reservoirs. Ever increasing population of the states, climatic changes and wastage of water in years old cultivation methods is producing demand-supply gap and now nations, nationalities and constituent units of federal states are moving towards confrontation because of this natural gift.

Pakistan is also a federal state that has agricultural based economy and where sharing of water is a major cause of conflict between federal units. Water distribution is a constant source of threat for federation of Pakistan and an unending dispute between Punjab and Sindh as well. This dispute is challenging the spirit of federalism in Pakistan (Waseem, 2010). Pakistan has two main systems of rivers i.e., "Rivers' flowing into Arabian Sea and Endothecia river basin". The former comprises; Indus river basin, Lyari river, Hingol, Hub rivers. Later comprises of: Mashkal, Siastan basin, Indus plain etc" (Ranjan, 2012). Among these rivers, the Indus river that enters in .Pakistan from along with its tributaries has the vital importance for the state and provides the largest contiguous irrigation system in the world to Pakistan .Besides this largest irrigation system the small federal units of Pakistan has their reservations against Punjab over sharing of water.

In fact this challenge is not new, it is continuing since 1859 right from the beginning of the British colonial rule in India. It started when undivided Punjab started preparing irrigation schemes over Indus River. It is universally agreed law that the significant right over the river belongs to tail users and the upper users has to construct irrigation projects with the consent of lower users. Sindh is the tail user of the River Indus and its entire tributary and thus holds the final rights over the water of Indus River. The province of Sindh along with Baluchistan has been opposing constructing dams and barrages as they complain that these provinces does not get their right share of river water because of over use by rest of the provinces. They also claim that these provinces divert water without the consent of the lower riparian areas. (Rizvi, 2014) As a matter of rights, equitable distribution of irrigation water among all provinces should be instituted. Presently, the biggest issue on debate is that Punjab forcibly appropriates a major and disproportionate share. This dispute is a persistence danger for the federation and a major source of conflict among the provinces to build new dams, which should be resolved through federal principles and international laws regarding water sharing.

The disagreement over distribution of water is another bone of contention between the constituent units of Pakistan. The difference of opinion lies over the construction of Kalabagh Dam, Greater Thal Canal and the distribution of Indus water between upper riparian and lower riparian. Earlier, the dispute over water distribution was settled down between India and Pakistan through the Indus Basin Water Treaty in 1960. This treaty gave exclusive right to use the water of three eastern rivers (the Beas, the Sutlej, and the Ravi) to India and three western rivers (the Chenab, the Jhelum, and the Indus) to Pakistan. However, the distribution of water within Pakistan remained problematic. Various committees and commission were constituted but adhoc sharing arrangements was followed up to 1990 due to lack of consensus. Finally, during Nawaz Sharif's premiership, in 1991, unanimous Water Apportionment Accord was signed by the four provinces and ratified by the Council of Common Interests (CCI) (Rajput, 2005).

Another water issue among the provinces is the Greater Thal Canal. The Indus River System Authority Accord (Irsa) had provided the certification to the Greater Thal Canal project with a 3-2 
majority. This canal would irrigate some15300oo acres in four southern districts of Punjab, including Bhakar, Jhang, Layyah and Khushab, and would have a total capacity of carrying 8,500 cusecs (Faraz, 2002). The Sindh has objected to the plan and Sindh Assembly has „passed a resolution to stop the ongoing construction of the Thal CanaL (Sayed, 2005).

\section{Conclusion}

It is good sign that federalism in Pakistan in now working smoothly after the military rules. After the democratic regime of Yousaf Raza Galani that was started after the elections 2018 one more parliament of Pakistan has completed its term from 2013 to2018 and in 2018 once again democratic transfer of power took place when PTI government replaced PML-N's government. This democratic journey is a healthy exercise for power sharing and for centre province relations. The mode that was adopted by introducing 18 amendments to the constitution has now turned the federalism of Pakistan towards the collaborative federalism. Now federal governments are running the affairs of state with the consent of federating units. Although from 2008 to 2018 different political parties came into power in different provinces but unlike past federal governments made no interventions, Federalism in Pakistan is still facing some challenges like issue of the southern Punjab Province, under representation of provinces in political and bureaucratic positions, corruption among the leaders of federal based political parties ,complete merger of FATA to KPK and share from NFC Award for the development of FAT development in the neglected areas and construction of the new water resources but all these challenges could be solved by adopting the collaborative model of federalism.

\section{References}

Ali, E. B. (2017, August 21). Kalabagh Dam and Reservoir-A Gold Mine. Islamabad, Pakistan : The Nation.

Anderson, G. (2008). Federalism An Introduction. Oxford University Press.

Faraz, H. (2002, May 8). Irsa Okays Thsl Project:decision taken on Split Vote.

Mushtaq, T. (2017, January 20). Kala baagh Dam, the Facts. Pakistan: The Daily Times.

Ranjan, A. (2012). Inter Provincial water sharing conflicts in Pakistan. Pakistaniaat:A journal of Pakistan Studies , 102-122.

Sajjad, A. a. (2015). A Tortured History:Federalism and Democracy in Pakistan. ISAS working paper no.2016 . Singapur: National University of Singapur.

Sayed, H. s. (2005, APRIL 7). Standoff between Sindh and Punjab: Greater Thal Canal. Dawn .

SHAH, S. M. (1994). Federalism in Pakistan Theory and Practice. Islamabad: Chair on Quaid- i -Azam \& Freedom Movement,National inistute on Pakistan Studies.

Shehbaz, R. A. (2015). New Threats and challanges to federalism:In Pakistan(A Socio Political Scenario). Journal of Political Studies .

Waseem, M. (2010, August). www.civic education.org/wp. Retrieved september 6, 2017

Zakir, H. (2005, December 2). ANP blasts Kalabagh dam'. Times 